\title{
Ali Shariati's Use of Traditional Media and the Historical Memory for Promoting Islamic Revolution in Iran
}

\author{
Ali Asghar Amini Dehaghi ${ }^{1}$ \\ ${ }^{1}$ Islamic Republic of Iran Broadcasting, Tehran, Iran \\ Correspondence: Ali Asghar Amini Dehaghi, Islamic Republic of Iran Broadcasting, Valiasr Street, Tehran, Iran. \\ E-mail: Amini779@yahoo.com
}

Received: December 2, 2015

Accepted: February 17, 2016 Online Published: March 18, 2016

doi:10.5539/ass.v12n4p37

URL: http://dx.doi.org/10.5539/ass.v12n4p37

\begin{abstract}
The thing that has always made Shariati immanent, according to some of his fans, in addition to his companionship conscious in first period and reforming in the second is Shariati's use of social communication process in form of traditional media which is usually about Shia clergy.

Plus, in order to have a stronger impact on his contacts tried to de familiarize traditional concepts especially religious and historical-myth memory community in the process of extraction and refining from religious historical concepts. So when audiences were exposed to the message of Ali Shariati in the traditional communication process they imagined it was a manifestation of religion with the concept of revolution, which had never happened before. Therefore Shariati was one of the most successful intellectuals in contacting with the audience, someone unprecedented in the history of Iran.
\end{abstract}

Keywords: traditional communication, the first Shariati, the last Shariati

\section{Introduction}

Ali Shariati is one of the pioneer intellectuals from the decade before the Islamic Revolution that today even after four decades from his death there are always serious critiques and approaches done to his intellectual discourses in different ways. And this indicates Shariati's intellectual life in that era which still continues in religious and secular circles between fans and especially new Shariatists. Because some of the issues that he used to study in his own time or was sensitive about is now explainable and debatable in Iran's everyday issues society, especially religious reform. The examined matter in this study is the way Shariati has influenced the process of communication in the circle of his audiences, because not before the revolution nor after it there has been no one successful like Shariati to persuade the audience, although there has been criticism to his work including his way of relating with the mass. However, why does Shariati act so influential in the communication process of traditional media? That in terms of cultural - intellectual infrastructure is known as the teacher of Iran's Revolution (1979), because with extraction and refining of historical memory prepared the Iranian society for a socio-political change in the concept of revolution. And Ayatollah Khomeini, as an exception, led the largest political parties in the form of a revolution after the death of Ali Shariati. A historical memory is more of the shared experiences of people in forms of ethnicity, nationality, crowd, people, groups, institutions and even organizations at times such as crises, movements, revolutions, wars, defeats, victories and etc which is called consciously or unconsciously and causes the same mentality in society, will be especially the influence element of social emotions in the areas of identity creation. Now, the historical memory can be made based on the actual date or it can lead to the emergence of common sense on the mythical history of the society. Historical memory itself will not be able to make a call, mentally or emotionally. It requires the knowledge of the history of social communication, in traditional or modern media, to call cultural symbols, rituals and traditions so they are in circulation in the social mentality and social communications media (Baravati, 2014).

Historical memory can work as a common mental element between the sender and the receiver known as the audience, in the communication process. Thus any kind of relation between the sender and the receiver with the common mental element of both sides can ease the process of influencing, especially in "persuading" the audience. Such as when audiences receive a message from the sender, regardless of it being a traditional or a modern media, because of the common mental element in the historical memory field will act as an effective factor in audience's judgment. Especially if the sender wants to send their messages to target audiences based on 
historical memory as a community post and the historical memory is based on myth and cultural and religious beliefs of the community. Surly the role of emotional factors also influence the audience will increase significantly due to a mythic history. For example when a Shia clergy uses a traditional media such as pulpit (Religious Tribune) of a mosque or a Husseiniyeh to send a message of justice containing Karbala and the martyrdom of the third Shia Imam, to the audience, meaning people present in the mosque, will definitely have a greater impact, because this clergy is using the mythical common historical memory that has happened in the third Imam of the Shia uprising in Karbala; Because the audience will experience a common mental-emotional factor. There will certainly be a special bond formed between the two sides due to calling a mythical part of the history they share. Thus, Recommendations message of justice following the call of historical myth of Karbala uprising makes the audience to accept sender's message from traditional media channels, that it is a common based mental - emotional belief without any rational judgment. On the other hand, there is a common mental factor formed between the audiences present in the mosque's spiritual message by traditional pulpit. If the same message of spiritual seeking justice is sent through the radio (modern media) to contact audience in the historical memory - the mythical uprising in Karbala common mind-sharing occurs between the audience (recipient) and clergy (the sender) but without the audience knowing each other face to face, because of the physical distance between them, a type of herding mind-sharing emerges. In other words, most of the people, as audience, experience mind-sharing without meeting each other or even living close to each other and form the mass society in terms of media. In addition to that, the common religion between the sender and the receiver of the message, according to traditional media which are mostly based on religious Shia beliefs in Iran, adds double influence of emotional and ideological impact to the message itself because most of the traditional media in Iran are way more trusted compared to other modern media such as the internet, television, radio and etc due to the religious origins of the Shia believers. (Brief look At Security Problem in Islamic Republic of Iran)

Although the people with religious beliefs having faith in traditional media messages help increase its influence on Iranian society in general, but more importantly is traditional media with mechanisms that lies in the nature of historical memory recall of traditional Shia media, Especially the mythical kind. There is no way that the traditional media is used anywhere without recalling mythical history and religion. Including the shrines are shown in the traditional media as fetching part of the historical memory of the Shiite sect, in facing the believing audience. Naturally, this provides some sort of emotional attachment to their fields of ideology derived from historical memory. Plus historical-mythical recalls, especially in religious fields repeating in the same times of the year such as recalling the Karbala uprising and the events related to it. Possible areas of sacred activism, exaggerated activism may be formed in promoting the historic elements of the process repeated every year. And the excessive dependence on historical memory in the Iranian Shia society makes people relive the events that are being recalled every time and every year when it's Muharram and Safar it is as if people have travelled back in time and relive the whole situation. Everything in the cities, with the support of Islamic political-Shia government travel to the mythic events (using historical memory) using symbols and signs. And all the social, political, economical and cultural actions and interactions are affected by this mythical historical memory. Even when it's not Muharram and Safar time these memories are relived in a weekly or monthly period and appropriate with the current time style. In other words they depend on this matter so much as if they are in constant communication with its historical past, a phenomenon that may not only effect its present but our future too by the constant readout of this historical- mythical memory. (Dehaghi)

In the Iranian Shia culture there is a kind of twofold life based on insecurity due to the subjectivity out of tyranny that has continued throughout the history up until now, in a way that what they think differs from what they do and Iranians live in an imaginary world in terms of culture-politics and the imaginary part is interpreted as country's culture. Therefore, in this culture given in the Iranian mind, poets raise due to the constant imaginary recalls. This mental dependency is so strong in Shia believers' minds as if the real mythic characters are observing the recall by their side. And this process is now so intensified that believers repeatedly returning to this unconsciousness especially after the Islamic Revolution and the rise of the clergies and improvement of traditional media, has become a psychological act, to the point that it has enhanced a social and even political illusion, talking pathologically and it has had negative effects on Iranian lives and interferes in them through media (even TV and radio). In a way that at times of inability to solve problems related to developing plans for the future, they unconsciously reach out to historical memory, especially in the form of a myth and are emotionally looking for a solution at the heart of them. (Ali Shariati-infinite zeros in front of a one. Tehran / before the revolution in 1967)

Memories, often selectively engineered from religious-political institutes in a form that pieces of historical memories is separated from its truth and then operated in vacuumed and such situations at mythical historical 
readings. The society on the other hand will surely seek the myths to complete the puzzle this matter has created. Therefore, in this arena, the boundaries of social imagination and subconscious memory will be altered. On the other hand, when the historical memory of the myths are so intertwined with religious beliefs, subsequently manifested fields rituals, rites and religious traditions in the symbolic dimension based on social needs will be manifest from the historical readings to the unity of religious identity. (Dehaghi)

Sometimes sacraments play such powerful roles according to political - religious needs that will impact on the nature of religion in society as far as religion is often out of context, moral, intellectual and spiritual appear in ritual and theology oriented form and the society is devoid of religion and moral sighted wisdom; Because religion ritual can meet the kind of emotional vacuum with resorting to psychological terms. Subsequently, any religious act will be demonstrated as fake. That is why religion ritual the power of traditional media in the social sphere in order to strengthen people's emotional ties with religious elements takes place through the reading of historical - mythical memory.

In a political - religious system, it is the religion ritual that can establish an emotional bond between people and theocracy in the process of political communication; because the believers connect to religion emotionally through the ritual symbols and signs, a religion with a completely romanticism nature; Trying to find the form of a ritual through its custodians. This is the way a religious and political system could demonstrate the legitimacy and authority in religious terms and to contribute to the development of public opinion in religious ceremonies. Thus, populations that are formed on the basis of religious rituals are in priority compared to populations that are civil in nature. It is always tried to further strengthen and protect these populations' faith-based approaches. Kings in the time of Shia Safavid Empire, especially Shah Abbas (1629-1588) in addition to strengthening the jurisprudence, attempted in rituals of Shiite, more than anything. Including, to strengthen Iranian national identity based on mythic-historic memory, make some Christian rites in Iranian form and rituals-from eastern Europe in order to reinforce the myth that are born from the heart of Shiite memory of Iran. Most of these regulations are formed and engineered within the Shiite rituals to strengthen the bond between people and the government through these rituals. In addition to that, warn the emotional feelings of the community about the Sunni Ottoman Empire, In terms of making an enemy. Shah Abbas even based on the historical memory of the legendary, intending to strengthen the system of rituals especially in the political governance structure, embedded a ministry under the name of Quite the Shrine to selectively and from historical memory and the influence of other faiths, regulate the media Shiite rituals in the process of political communication in order to direct the public thoughts. Thus restoring faith in this community's communication system suggests systematic and selective exploitation from mythic-historic memory which Safavi kings always used this way to manage the mental sphere. In addition to the efforts of Clergymen based on strengthening jurisprudence-oriented thinking in keeping with the Safavi kings to legitimize religious political rule of the Safavis and undoubtedly, the strengthening of public opinion is done through ritual communication and clergymen used the communications media and religious ritual to develop the legitimize networks in the minds of all religious believers; because the influence of religious (Traditional) communication processes does not need any arguments but is based on prior knowledge or the historical memory of the mythical approach, audience's unconscious in the communication process towards such messages what are embarked on a religious historical memory, has no resistance to rational analysis of a message from the traditional media. And in this historical memory there is an enemy who stand against the myths and the war between these two (although hypothetical) has a constant effect on our religious and cultural beliefs, because the subject of a religious enemy appropriate to our times and as a threat legitimizes clerical domination consistent with political. Therefore the concept of enemy and myth in Iranian religious history are continuous. Therefore, as the conflict in the Shiite community, usually the shadow of insecurity and fear is continuous in the political culture. Consequently, in its identity and integrity will play a fundamental role in the Iranian -Shiite community. As if its life is impossible without the presence of the enemy; even though imaginary and hypothetical. Therefore there is the existence of a Thoughts Enemy ideology consciously and unconsciously for Iran to strengthen the national identity and political culture of religious life. In the traditional media, the sender of the message such as a clergy at the pulpit (religious tribune) gives speeches in the mosque for the audience (religious message receivers), this way they can easily show their reaction to the message they have received. And the sender can also get a general understanding of what the audience is thinking about his speech even through their facial expressions. Therefore this communication is not only a two-way interaction between the sender and receiver but is also an emotional action and reaction between them. A clergy can easily discern the psychological reactions of his contacts and alter his speech at the time of getting feedbacks. This way of traditional communication is still going on in places like mosques, husseiniyehs, shrines and seminaries and clergymen are able to change and modify the public thoughts through it and it also enables them to play the roles of disputer, advisor, assistance and etc in fields of politics, social and even economics; such hypermedia 
activities improves the clergymen's effectiveness on the audience due to the trust that has come between them; Although the binding of these messages is due to traditional media impacted by a religious- sacred atmosphere which is important in the effectiveness of the message because of the surrounding circumstances and prepared background. On the opposite side of Iran's clergymen's successful approach, are the Iranian intellectuals who do not understand the relevance of the community yet try not to go further than the argument in the process of social communication and want to see and test everything with their own wisdom and today some of them, despite Ali Shariati's approach, do not discriminate against intellectual vocation of man and society and consider themselves responsible for their own mind more than anything else; As a result, the sense of reality in the realm of thought is not pleased to them and they even accept culture to the point that his own wisdom allows. Therefore considers anything with the extension of "intellectual" if it is to be added to "religious" in contrary to their rationality and thought. Thus most of the intellectual experiences in this layered Iranian society were and still are focused on account of modernity against tradition and today we don't see much of it getting to beyond the conflict between tradition and modernity, and social pain such as justice. (Ali Shariati-infinite zeros in front of a one. Tehran / before the revolution in 1967)

Yet there are still many definitions proposed for intellectualism that indicates the critical concepts in the area of this matter. As a result, the purpose is the pain of the intellectual in the same time as his reasonability. (Papaioannou \& Olivos, 2013)

In early modernity in Iran because of the noble intellectuals origin request, led to their narcissism in the early Constitutional Revolution, not having any sort of interest in making connection with other parts of the society and the most important reason was that the intellectual language is a process purely understood only by a fellow intellectual (as they call it themselves) and sometimes even the concept is different than what it was originally intended to be. Because the intellectual language is not in the position of contradictions and conflicts to acknowledge it as systematic and the owner of communication; thus not only most of the intellectuals get trapped in words game but they also get confused unwontedly. In addition to the environmental problem of personal style and character, they do not have a way to communicate with different social classes. In other words, as the sender of the message, not only they don't follow a certain pattern but even after the process of contacting the audience they have no mechanism for receiving and understanding their contacts' reactions to the message they have just sent and thus easily ignore the matter. Therefore most intellectuals always speak unidirectional and usually do not have an understanding of the relevance of understanding the nature of their contacts, except for Ali Shariati who for example spent a lot of time studying the reactions to his one hour speech at husseiniyehs ershad. The approach that clergymen use traditionally in their media communications to understand the reactions of their audience (however not academic) helps them to notice the private and public reactions of their audience. Ali Shariati's achievements, despite of the critical statements about him, is because he used to try to use clergymen's approach of traditional communication style to influence and persuade the audience, so he could have a two way communication with all classes of society, because he even believed that intellectuals must learn the language of children too. He also used common prognosis in his speeches such as the historical-mythical memory; so it is obvious that he tried to have both modern and traditional approaches used in his way of communication and he even had the ability to use concepts of socialism in its simplest means of communication, in order to help the audience to understand better. Considering this, Ali Shariati is the only intellectual who could truly have an impact on his audience in different ways. An impact that even clergymen appreciated although he believed Islam must be separated from clergies. Shariati used three different processes of communication consisting of Demographic trends, expression - emotional Realm and normative - modeling realm. In a way that after couple of decades there are still new Shariatists who try to comprehend and adapt the old sayings with today's society and Shariati was so strong in communicating with his audience that his thoughts and saying are still true to this time; meaning not only he was the sender and the author of the message but he also played the role of the intellectual and the interface which not a lot of intellectuals have been capable of. Meaning Shariati authored the character of Abouzar in the form of a play as the sender and then even decides to direct the play himself, only to make the society more familiar with Prophet's companions. In other words Shariati, in the process of defamiliarization art from historical texts, creates Abouzar who was very new to the pre-revolutionary society of his time. Some of the directors even tried to make artistic images of what Shariati believed in, in its generality. Although some were not attached to intellectual concept or transfer interface of manufacturer's enlightened views, publicly speaking. Because according to intellectual definitions, this role cannot be explained as an enlightened look coming from some intellectuals. Thus, any intellectual can play the role of the interface or transmitter himself, something that happened in Iran only by Ali Shariati. Meaning he both defamiliarized Abouzar and introduced him in a play as a director and his audience could also get to know socialist character of Abouzer or Prophet Muhammad. In addition to Shariati's outstanding individual characteristics he is the only 
intellectual who despite intellectuals before and after the Islamic Revolution in Iran is successful at the relationship with the urban populace. As Mustafa Malekian said, Shariati was an exception in communicating with the masses, nobody else like him. Shariati could use the triangle conversation of power, wealth and deception, or in other words Gendarmes, Khan and Mulla, given the prevailing atmosphere of leftist among intellectuals, invited his own people to identity readout and based on society's religious beliefs secularization of religion to bring it down from heaven to earth so that religion can act ideologically in public life of a man. In addition to pulling down religion and stimulating it he tried to, as a warn people in a society stuck in the triangle of power, wealth and deception. As if in a short time, he didn't see anything more necessary than to scream for a society asleep (during his speech at the hosseyneye ershad). So in the first period of vita he appears more than a religious reformer as a religious and social warning. Therefore in his way of impacting the audience he chose a style of extraction and purification and then defamiliarization of historical-mythological memory demanded by his time; and commensurate with his past experiences, he has an exceptional language among past and current intellectuals. When audiences were exposed to his messages and concepts of language they immediately showed sympathy. Thus, most of his audiences were present from left, religious and national intellectual beliefs. One of Shariati's achievements was that he could gather these conflicting political-cultural matters all together with their inclusion of communication, using hosseyneye ershad's traditional media and force them towards a revolutionary movement with a common goal in mind. Especially to have a new message for the dominant discourse of the leftist intellectuals in Iran influenced by liberation theology left for enthusiasts and subsequently have something to say as a warning for people who are inspired by the pioneers of modernism and religious revivalism such as Jamal al-Din al-Abadi, Iqbal Lahori and etc; and most importantly gather all these conflicting matters identity area. Undoubtedly his existential language and perspective were his most important factor in relating to his audience. Thus, not only he uses addressing people in his speeches but he used argument and reasoning less for stronger impacts, because Ali Shariati's goal is to warn people. Even if he attempts for the extraction and refinement of the historical memory of the Iranian society, more than anything else he made the choice to follow the socialist character of Shiite approaches to be able to meet the needs of the audience's leftist. Thus he identifies and introduces the personality of Imam Ali as Shiite's first Imam in a way as if he was the first socialist theist in Shiite beliefs and Iranians were unaware of his existentialism aspect and he defamiliarizes Imam Ali in a way that no Shiite has ever known. 9.14.These extraction and refinements from religious resources and from historical memory filter of the community too, made the conservative clergymen who didn't care much about the issue of social justice and warning style of the leftist disturbed, especially when Che Guevara's armed uprising resembles to Imam Hussain's Karbala uprising in his Hosseynie Ershad speeches. Naturally, Marxists audience of Shariati had sympathy for him and fought the religious spectrum. Shariati tried to mention the existentialism matters between leftist and religious audience that every human being is affected by in some way to establish a revolutionary attitude in the minds of a new generation through a poetic language for a major revolutionary goal. Thus, the safety of the Pahlavi monarchy (Before the Islamic revolution in Iran) considered Ali Shariati's thoughts as producing a kind of fusion between Shiite and vulgar Marxists called "Islamic Marxists" which according to most clergymen who generally considered the formation of MEK as a result to Shariati's speeches and his tribune in Hosseynie Ershad and his communication activities to the point that Hosseynie Ershad was changed to the base of absorbing new members. An organization with fusion of the two vulgar religions and Marxism with a focus on Shariati's innovation-mongering that could form a reading of religion crusader with justice approach with reading modern and revolutionary conjunction, derived from the historical memory of the community and the members considered themselves not students but his spiritual children. In any way, making a common ideological form of religion by Ali Shariati's innovative readings, especially where he introduces Islam without clergies, definitely enters Shariati to a challenge with clergymen to the point that some of the great ones called him heretic. Due to the pressure coming from these great conservative, always at royal service clergymen, Hosseynie Ershad was closed to stop Ali Shariati's speeches. But then two clergymen like the Ayatollah Khomeini and Ayatollah Taleghani exceptionally and despite prevailing conservative attitude of the clergy, had justice views and always cared about the poverty issue in Iran. When Shariati's warning signs which were inspired by religious socialist-liberation motives theology in Latin America, moreover, religious leftist culture of Algerian Revolution in Iran's society before the revolution, could ideological up the Shiite Islam and organize guerrilla groups whether religious or leftist, towards a revolution against the monarchy, despite the anti-Marxists result that SAVAK expected from the mass of Shariati's audience noticed a continuously growing of Islam and sharia-inspired guerrilla vulgar Marxism which was usually in the form of MAK and committed armed movements against the monarchy. And SAVAK had to arrest Ali Shariati who had generated this new religious attitude and received fight tactics from vulgar Marxism and liberation theology in South America in 1974. Perhaps the second half of the sixties was the time of guerrilla groups getting suppressed during their execution; 
including religious spectrum (MAK) who SAVAK called Islamic Marxists or the Left Marxist-Leninist groups such as Fadaiyan Irregular Troops who didn't commit to religion in theory. But indirectly affected by the selection of readings by Ali Shariati, took revolutionary use of the historical memory of Iran and for this reason in the military courts of Shah (Second Pahlavi) the arrested people of this matter, despite leftist Marxist views, had idols from religious myths of the historical memory of the pre-revolutionary Iran who Shariati described for his audience. And that is why what Shariati started, covered all the groups in fight with Shah, directly or indirectly. The last step of arresting Shariati (1972-1974) which took 18 months caused major alternations especially because of his poetic and existential sense in prison and after his freedom. Although there are different contradictory news about his freedom (Dehaghi):

1. Shariati's collaboration with SAVAK that had been going on before this period and basically the project of Hosseynie Ershad was under SAVAK's control to stop Marxism in the society.

2. According to SAVAK's strategy Shariati tried to keep his own project going in within SAVAK's project, hence his subtle interactions with them.

3. Shariati never collaborated with SAVAK as an appointee, something acknowledged by some of his inmates and know his projects as tricks to prevent their growing influence in the political and militant groups. (Davodi, Maghsoudi, Fami, \& Kalantari, 2013)

Arresting Shariati caused a lot of in-group disputes among MAK members. Meaning violent conflict between supporters of the Marxist and religious followers with SAVAK repression weakened MAK to its lowest point. Shariati also, was almost on the side of the religious followers and was quite hurt by the murder of some of the members by the Marxists. Plus Shariati's motivations in this state are not quite clear that what exactly happened to him in prison, emotionally, which even made him become depressed and a loner after his freedom in 1974; in a way that his thoughts and speeches had completely altered, hence the title the last Shariati. (Dehaghi)

Despite the warnings Shariati used to give in sixties, in this level awareness replaced the revolutionary upsurge; in other words the Prospective identity conscious Shariati turns into the knowledge-minded reformer Shariati. In this very short period, Shariati supports mysticism, equality and freedom and the concept of man in society becomes more important to him (Zarif, 2014).

One of the reasons behind this alternation could be the murders happening among his students that made even lonelier, in other words he falls into the realm from the outside world intentionally or unintentionally. Although he had a stressful spirit from his early stages of youth, but he wanted an intellectual molting after getting out of the prison. Although he was one of a kind among initiators of religious intellectuals but a knowledge -though alternation is quite natural for intellectuals, thus an intellectual's words and thoughts change throughout his life according to his experiences and surroundings; Especially an existentialist intellectual who is raised in Iran's Shiite political and cultural field. Therefore, not only Shariati is a pioneer but he also selected his subjects appropriate to his time and the pretexts of a warning might have means of a tool too. Although the nature of Sharitati's intellectualism was developed on time's needs, it was at first welcomed by the educated class of the society. It seems like his understandings of Iranian society has a warning aspect more than anything else, hence his emotional approach with his audience and he also uses traditional media and emotional aspects consistent with historical memory, that have properties of classical persuasion; but after his internal transformation his words transform into discourse and awareness too which is why he must take advantage of rational communication which his short life until his death (two years) didn't give him a chance to do so. Shariati almost touches that last scene of change when he goes to jail. After his freedom when he sees how the society is under high security watch and how the government is worried he knows that is because of people's social-cultural awareness; to the point that he notices he cannot continue his old way to warn people; after two years of tension from within and without he had to secretly leave Iran. (Nature of Iranian Traditional Median Political communication Process)

Although Shariati could send the informing and reforming message to some extent in the second stage of his intellectual life, but he didn't find a chance to take that to his audience in the process of social communication. Thus, the audience of the First Shariati was prepared for a major social, cultural and political change which after Shariati's death, Ayatollah Khomeini took the lead using traditional media instead of modern royal media (TV and radio) to take the revolution seed that Shariati had implanted to the next level due to the charisma he had found. To sum up, the society that was under Shariati's awareness (not reforming) influence built up a theory-less revolution. However, Shariati was a pre-revolutionist ideologue and not a revolution ideologist because his short life didn't give him a chance to take it to the next level. As a result, people were able to take the lead rope that had the monopoly of traditional media and traditional communications network for mass 
public opinion or were official interpreters of Islamic religious -historical memory.16 Thus, Ayatollah Khomeini led the Iranian revolution after Shariati's awareness, not his intellectualism which is why Shariati's religious reforming project got canceled after the revolution; But in persistence of Shariati's religious intellectualism some of Shariati's followers especially Abdulkarim Soroush, despite Shariati's ideological approaches, again, using traditional media and religious -historical memory. If Shariati took religion from heaven to bring it to the community; Soroush tried to restore religion to suit the Muslim community of the time and to remove ideology from religion. He worked for his religion in the post-revolution society like Ali Shariati who today, after 37 years of revolution who tried to review his own attitudes, following the reform of religious thoughts and experience commensurate with the passage of time due to a leftist culture in Iran before the revolution. (Ricoeur, 1996)

\section{Conclusion}

What makes Shariati special among the intellectuals before and after the revolution has got him under the review of the pros and cons. His feature in the operation of cultural national-religious resources is in order to recall ourselves that could communicate with the society as a leading religious intellectuals using language identification. More importantly Shariati used extraction and refining of historical memory and myth in Iranian-Shiite religious community to defamiliarize religious concepts popular in his time that was dominant left culture. And he tried to warn his community through persuasion in the process of social communication without the traditional philosophical arguments. That's why Shariati believed intellectuals should initially learn the language in society to target relationships. He even insisted that they should learn the language of children. This indicates that Shariati was also aware of social communications especially the traditional media.

Because he could use communication mechanism with two warning and reforming approaches relate to the educated class of the society despite other intellectuals in the field of intellectual activities.

Shariati's early activity is considered the time for warning to seek identity readout for promoting a revolutionary upsurge. And in the second part of his life, which was quite short, he didn't get the opportunity to teach about reforming the religion of man's awareness of the issue. But his warning project which was engineered according to people's needs of that time got a whole lot more attention and most of the criticism around his work is about his first period of life. While Shariati review must be about the evolution of his term discourse of mysticism, equality and freedom as well. However, Shariati despite his young age had a huge role in the revolution of 1967 in Iran which indicates his ingenuity.

\section{References}

Ali Shariati -infinite zeros in front of a one. Tehran, published in 1978 (this edition of the writings of Shariati was for militants who were sent to the revolution a year before. It has no certificate).

Ali, H. (2013). Revolutionary Posters as Sites of Historical and Religious Memory (Doctoral dissertation), Roosevelt University.

Baravati, M. Z. (2014). Practical Analysis of Right of Preemption in Islamic Penal Code.

Brief look At Security Problem in Islamic Republic of Iran. Retrieved from http://www.eurofeanjournalofscie ntificresearch.com

Davodi, H., Maghsoudi, T., Fami, H. S., \& Kalantari, K. (2013). Evaluation of strategies for developing the agriculture technology in the science and technology parks of Iran from faculty member aspect. African Journal of Agricultural Research, 8(30), 4148-4156.

Dehaghi, A. A. A. (n. d.). Formation of Public Opinion to Update Rumors. Retrieved from http://www.lifesciencesite.co

Dehaghi, A. A. A. (n. d.). Iranian Cultural Homeland. New York. Retrieved from http://www.Sciencepub.net/

Dehaghi, A. A. A. (n. d.). Nature of Iranian Traditional Media in Political Communication Process. Retrieved from http://www.americanjournalofscientificresearch.com

Fotouhi, S. (2015). The Literature of the Iranian Diaspora: Meaning and Identity since the Islamic Revolution (Vol. 5). IB Tauris.

Melikian, M. (2014, June 29). Iranian Intellectual Difficult at Process of Social Political Communication Interview with Iranian philosopher and intellectual.

Nature of Iranian Traditional Median Political communication Process. Retrieved from http://www.sciencepub.net/academia

Papaioannou, T., \& Olivos, H. E. (2013). Cultural identity and social media in the arab spring: Collective goals 
in the use of Facebook in the Libyan context. Journal of Arab \& Muslim Media Research, 6(2-3), 99-114.

Peterson, M. A. (2015). New Media and Electronic Networks. A Companion to the Anthropology of the Middle East, 27, 509.

Ricoeur, P. (1996). Journal of conversation. Retrieved from http://www.lifesciencesite.com

The Responses of Iranian Intellectual and the methodical Disorders. Ali Shariati-infinite zeros in front of a one. Tehran / before the revolution in 1967. Retrieved from http://www.jofamericanscience.org

Zarif, M. J. (2014). What Iran Really Wants. Foreign Affairs, 93(3), 49-50.

\section{Copyrights}

Copyright for this article is retained by the author(s), with first publication rights granted to the journal.

This is an open-access article distributed under the terms and conditions of the Creative Commons Attribution license (http://creativecommons.org/licenses/by/3.0/). 